\title{
MJFAS MALAYSIAN JOURNAL OF

\section{Influence of alkaline addition on the composition and yield on the hydrothermal treatment of rice straw}

\author{
Abas Sato, Arief Widjaja*, Khozin Asror, Ayu Rahma Emilia \\ Department of Chemical Engineering, Faculty of Industrial Technology, Institut Teknologi Sepuluh Nopember (ITS), Kampus ITS Sukolilo, Surabaya \\ 60111, Indonesia
}

* Corresponding author: arief_w@chem-eng.its.ac.id

\section{Article history}

Received 22 Mac 2018

Revised 24 July 2018

Accepted 31 August 2018

Published Online 25 August 2019

\begin{abstract}
Agricultural waste is abundantly available in Indonesia, including rice straw. The largest components of rice straw are cellulose, hemicellulose, and lignin, making this material good enough as raw material for production of biogas, bioethanol, and other renewable fuels. The bonds in the cellulose and lignin in rice straw are strong and difficult to degrade which consequently will block the microorganisms to degrade them. In this study, a hydrothermal treatment was performed with the addition of $\mathrm{NaOH}$. The purpose of this study was to investigate the effect of alkaline hydrothermal treatment on rice straw delignification, cellulose and hemicellulose solubility, the formation of reducing and furfural sugars, as well as the degrees of cellulose crystallinity. The variables used were $\mathrm{NaOH}$ concentration of $3 \%, 5 \%$, and $7 \%$ (w/w total solid) and temperature were $100^{\circ} \mathrm{C}, 120^{\circ} \mathrm{C}$, and $140{ }^{\circ} \mathrm{C}$. Treatment was performed using an autoclave with water and rice straw ratio of 8:1 with heating time for 2 hours. The results of this study showed that hydrothermal and $\mathrm{NaOH}$ treatment can increase rice straw organic degradation as indicated by increasing delignification of rice straw and increased levels of water soluble sugars. The higher the temperature and the $\mathrm{NaOH}$ concentration, the more lignin and soluble hemicellulose content. Meanwhile, the reducing sugar increases with increasing temperature and $\mathrm{NaOH}$ concentration. Thermal decomposition rate has also occurred at lower temperature. It was found that the highest organic rice straw degradation occurs at higher temperature and $\mathrm{NaOH}$ concentration.
\end{abstract}

Keywords:hydrothermal, rice straw, cellulose, lignin

(C) 2019 Penerbit UTM Press. All rights reserved

\section{INTRODUCTION}

Burning fossil fuels has contributed to the increase of carbon dioxide in the atmosphere, which is directly related to the increase in global warming. In addition, future energy security issues along with increased concentrations of carbon dioxide and methane greenhouse gas emissions have reinforced interest in the development and utilization of alternative, non-petroleum-based renewable energy sources or fossil fuels. The vegetable-based fuels produced from plant biomass have the potential to reduce the problem of global warming. Biomass absorbs $\mathrm{CO}_{2}$ during growth and removes it during combustion. Production of bio-based fuels will also provide new income and employment opportunities in rural areas.

Large amounts of agricultural biomass are burned each year in the open field/environment that releases harmful gases. The main concern of biofuel production is to produce renewable fuels from agricultural waste biomass in order to achieve the goal of sustainable development and ecology of planet earth (Silalertruksa et al., 2013). Lignocellulose/ agricultural waste biomass has great potential that is not used to meet energy/fuel demand. In order to produce sustainable fuel/renewable energy efficiently, lignocellulosic agricultural biomass fermentation becomes a good idea to develop. Rice straw is one of the most abundant agricultural lignocellulosic crops in Indonesia, with an annual output of about 76 million tonnes. Rice straw contains approximately $39 \%$ cellulose and $27.5 \%$ hemicellulose. Both are polysaccharide materials make it difficult to be directly fermented into biogas or bioethanol so that it requires pre-treatment process to make the materials become simpler compounds. The process of degradation of straw can be done by physical or biological means.

Lignocellulosic biomass pre-treatment offers higher levels of biodegradation and major product yields in the biological energy conversion process. He et al. (2008) reported that solid $\mathrm{NaOH}$ pretreatment on rice straw at $4 \%, 6 \%, 8 \%$, and $10 \%$ (dry weight base $\mathrm{NaOH}$ ) has increased biogas production yields from 3.2 to $28.6 \%, 27.3$ to $64.5 \%, 30.6$ to $57.1 \%$, and 15.2 to $58.1 \%$, respectively, compared to untreated rice straw for organic loading rates of $35,50,65$, and $80 \mathrm{~g} / \mathrm{L}$ in fermentation digesters. It was also reported that the highest biogas production occurs at an organic loading rate of $50 \mathrm{~g} / \mathrm{L}$. Alkaline pretreatment of lignocellulosic biomass has been found to cause swelling, increased internal surface area of polymerization degrees, crystallinity degeneration, separation of structural relationships between lignin and carbohydrates (cellulose and hemicellulose), and lignin structure disorders. Alkali pre-treatment also reduces the rate of inhibition during fermentation and provides a lower production cost compared to other pre-treatment methods.

The reaction temperature and residence time are two essential parameters in disrupting the lignocellulosic structure. The reaction temperature of $190{ }^{\circ} \mathrm{C}$ and the residence time of 5-10 minutes is high enough to destroy the crystalline structure of cellulose and 
hemicellulose (Sakaki et al., 2002). Smaller residence times of the reaction can save energy differently from longer residence times.

The lignocellulosic component prevents microbial cellulases from contacting cellulose by absorbing and physically blocking cellulases from contacting the cellulose. The bonding pattern between cellulose crystals and amorphous hemicellulose, lignin, and cuticle wool, which contains fat components and branched chain alkene complexes, alkene, fatty acid, esters, primary alcohols, and phenolic materials (Liu, 2009; Wisniewska, 2003), making enzyme activity very slow. Although the temperature is an important parameter for biomass, pre-treatment can increase the yield of glucose or decrease the biomass component that becomes the fermentation inhibition product. It has been reported that alkaline reagents including lime and ammonia have been proven to be quite effective at much lower temperatures over longer periods (Kim, 2005). Sodium hydroxide is a stronger base than lime and ammonia, and thus has better potentially to work at lower temperatures and shorter reaction times.

The aim of this study was to understand the hydrolysis behavior of rice straw biomass, untreated, and hydrothermal treated with the addition of $\mathrm{NaOH}$. Next, the current study aimed to present the comparability and comparative effectiveness of the treated substrate to improve methane fermentation for biogas or bioethanol production in order to produce better methane or bioethanol in large quantity. The treatment performance was measured against changes in chemical structure of rice straw using sugar, cellulose and lignin analysis, and degree of crystallinity analysis.

\section{EXPERIMENTAL}

\section{Mechanical pre-treatment}

Rice straw mechanical pre-treatment was performed by milling using knife mill to cut the size of $5 \mathrm{~cm}$. Knife mill grinding machine is capable of grinding dry biomass with moisture content up to $10-15 \%$ (Zheng, 2014). This pre-treatment was done to facilitate the process of substrate incorporation into the digester. In a previous study by Menardo (2011), mechanical pre-treatment on rice straw of 5, 2, 0.5, and $0.2 \mathrm{~cm}$ did not show significant increase in biogas yield.

\section{Hydrothermal treatment of rice straw}

In a study conducted by Chandra et al. (2012), it was known that the hydrothermal process results in the formation of acids. Therefore, the hydrothermal treatment was performed with the addition of $\mathrm{NaOH}$ to achieve a condition with $\mathrm{pH} 7$ which is the right $\mathrm{pH}$ for methane fermentation. The addition of $\mathrm{NaOH}$ content in this study was between $0-7 \%$ on the basis of dry rice straw. Hydrothermal treatment was performed in an autoclave made of stainless steel with 8 in diameter and has a volume of 13 liters. The autoclave was equipped with PID controller equipment for temperature control, pressure gauge, ventilation or exhaust valve, relief valve, and electric heater. The operating temperature of the hydrothermal process was $100-160{ }^{\circ} \mathrm{C}$ and residence time of 60 minutes rising temperature and 60 minutes at peak temperature. The pressure of this process is lower than the saturated water vapor pressure in the hydrothermal equipment due to the presence of $\mathrm{NaOH}$ base which will decrease the vapor pressure. An increase in operating temperature will lead to higher saturated water vapor pressure, which results in faster hydrolysis of the volatile material content but will increase the energy demand in the pre-treatment process. Longer residence time will cause pyrolysis, which results in charred biomass and also higher energy demand.

The exact range of alkalinity is very important for the methane bacteria that are formed during the methane fermentation process. Thus, the addition of an appropriate amount of $\mathrm{NaOH}$ helps to ensure enough alkalinity to neutralize the acid produced in the digester, since most anaerobic bacteria perform well in the $\mathrm{pH}$ range of 6.8 to 7.2. However, increasing cation concentrations of more than $1500 \mathrm{mg} / \mathrm{L}$ began to show significant toxicity (Gerardi, 2003). Therefore, in $\mathrm{NaOH}$ with substrate treatment the concentration level of $\mathrm{NaOH}$ was selected at 3\% (dry weight biomass basis). At the above level on the addition of $\mathrm{NaOH}$, the cation concentration in the substrate was $1,500 \mathrm{mg} / \mathrm{L}$ which is well within the noninhibitor range for methanogenic bacteria.
The $\mathrm{NaOH}$ solution was added to $0.2 \mathrm{~kg}$ of dry rice straw followed by water addition to maintain $12 \%$ of total solids concentration. The substrate was autoclaved, sealed tightly by shaking the cap, and ready for a hydrothermal process.

\section{Characterization of rice straw biomass}

Characterization of rice straw biomass was done by using proximate, ultimate, and standard composition analysis methods. Proximate analysis includes the determination of moisture content, total solids, volatile solids, and non-volatile solids (ash) of rice straw. Meanwhile, compositional analysis involves the determination of cellulose, hemicellulose, and lignin in rice straw biomass.

\section{Analytical method}

The composition of raw rice straw and treated rice straw was performed using Chesson analysis and DNS method. The Chesson analysis method is an analysis of the chemical composition of lignocellulose performed following the reference from Datta (1981). The gravimetric analysis include the following steps: (i) the elimination extractive content (in this method called Hot Water Soluble (HWS)); (ii) hydrolysis of hemicellulose by using strong acid without heating; and (iii) hydrolysis using dilute acid at high temperature.

$\mathrm{XRD}$ is an analysis technique to identify and determine the various forms of crystals. Identification is obtained by comparing the diffraction pattern with X-rays. XRD test was done by using Phylips Pw3050 type diffractometer equipped with APD (Automatic Powder Difraction) software and using $\mathrm{Cu}$ anode tube at wavelength of $1.54 \mathrm{~A}^{\circ}$.

\section{RESULTS AND DISCUSSION}

\section{Rice straw composition}

Table 1 presents the results obtained from the proximate, ultimate, and rice straw biomass composition used for methane fermentation research. Proximate analysis showed that dry rice straw contained $7.8 \%$ moisture and $92.2 \%$ total solids based on wet biomass weight. Volatile solids and ash content were found to be $89.9 \%$. In addition, compositional analysis showed that rice straw biomass contained $29 \%$ cellulose, $30.8 \%$ hemicellulose, and $11.6 \%$ lignin on the basis of dry weight of rice straw biomass. The composition analysis revealed that cellulose and hemicellulose are combined about $60 \%$ of the dry weight of rice straw biomass. This amount is the most widely available quantity for degradation.

\section{Composition of cellulose, hemicellulose, and lignin}

The analysis result of cellulose, hemicellulose, and lignin content by Datta method (1981) before and after hydrothermal treatment is shown in Figs. 1-3. Fig. 1 shows cellulose content after treatment at temperature of 100 and $120{ }^{\circ} \mathrm{C}$. There is a tendency of decreasing cellulose content along with increasing $\mathrm{NaOH}$ concentration, whereas at $140{ }^{\circ} \mathrm{C}$ the cellulose content increases as $\mathrm{NaOH}$ concentration increases.

Table 1 Component analysis of rice straw before hydrothermal treatment.

\begin{tabular}{lc}
\hline Component & Content (\%) \\
\hline Celulose & 29.06 \\
Hemicellulose & 30.82 \\
Lignin & 11,53 \\
Moisture & 7.81 \\
Ash & 2.28 \\
Volatile solid & 8.91 \\
Total solid (TS) & 92.19 \\
\hline
\end{tabular}




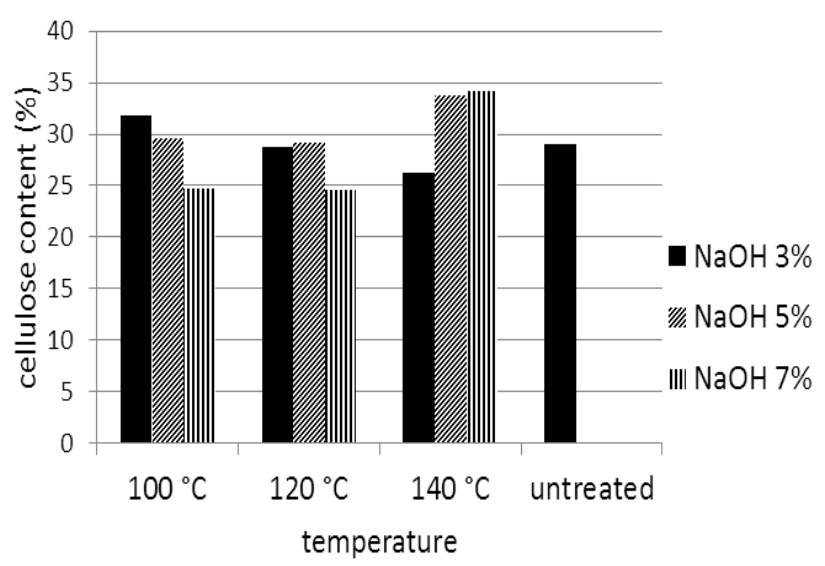

Fig. 1 Cellulose content before and after hydrothermal treatment.

This suggests that the reaction of lignin compound and carbohydrate complex of rice straw with $\mathrm{NaOH}$ causes the release of cellulose which then dissolved into water. In this work, there was also a decrease in cellulose content at 100 and $120^{\circ} \mathrm{C}$, which indicated the cellulose dissolved in water. While at $140{ }^{\circ} \mathrm{C}$, there was an increase in cellulose content in the solid rice straw due to the increasing number of dissolved hemicellulose and lignin. Sakaki et al. (2002) reported that cellulose start to degrade into hexose and oligosacharideat temperature above $230{ }^{\circ} \mathrm{C}$ while this work was operated only up to $140{ }^{\circ} \mathrm{C}$. Thus, only small part of cellulose dissolved into liquor product of hydrothermal treatment. Most of hemicellulose dissolved into water, the resulting ratio cellulose and hemicellulose plus lignin in the treated solid rice straw was consequently increased.

The process of hydrothermal treatment on rice straw showed the highest solubility of lignin content in treatment with $7 \% \mathrm{NaOH}(\mathrm{w} / \mathrm{w}$ TS straw) and temperature of $140{ }^{\circ} \mathrm{C}$ for 2 hours i.e. from $11.53 \%$ on rice straw without treatment to $6.33 \%$ after treatment. At the same operating condition, the most significant increase of cellulose content from 29.06 to $34.13 \%$ was recorded. While the highest solubility of hemicellulose content occurred at the concentration of $5 \% \mathrm{NaOH}$, and temperature of $140{ }^{\circ} \mathrm{C}$ with the decrease of hemicellulose from 30,82 to $17,33 \%$ (see Fig. 3). At temperature of $100^{\circ} \mathrm{C}$ and $140{ }^{\circ} \mathrm{C}$ there was an increase in delignification along with an increase in $\mathrm{NaOH}$ concentration, whereas at $120{ }^{\circ} \mathrm{C}$ there was an increase in delignification at a concentration of $5 \% \mathrm{NaOH}$ and dropped at a concentration of $7 \% \mathrm{NaOH}$. Delignification means the ratio of removed lignin content from rice straw during hydrothermal process to the initial lignin content. It was known that delignification increased with increasing $\mathrm{NaOH}$ concentration. Delignification also increased with increasing pre-treatment temperature, it occurs almost at all $\mathrm{NaOH}$ concentrations, but at a concentration of $7 \% \mathrm{NaOH}$ there is a slight decrease in delignification at $120^{\circ} \mathrm{C}$, and increasing again at $140^{\circ} \mathrm{C}$. The most significant percentage of delignification occurred

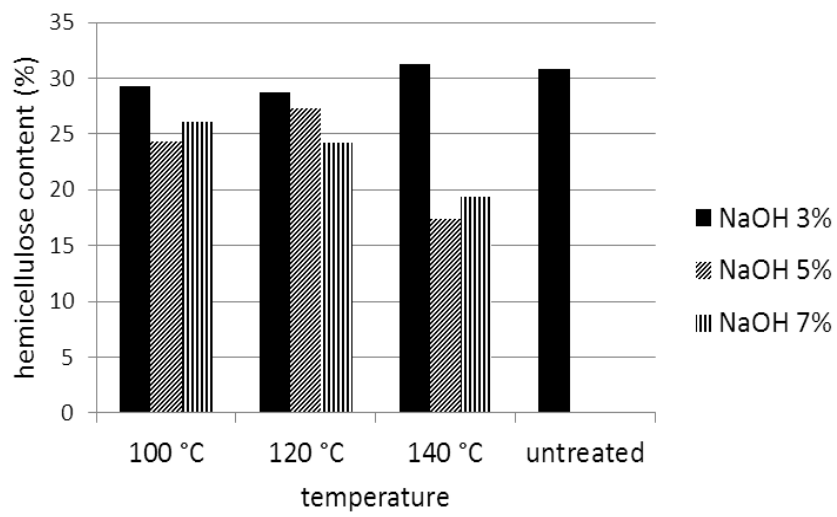

Fig. 2 Hemicellulose content before and after hydrothermal treatment.

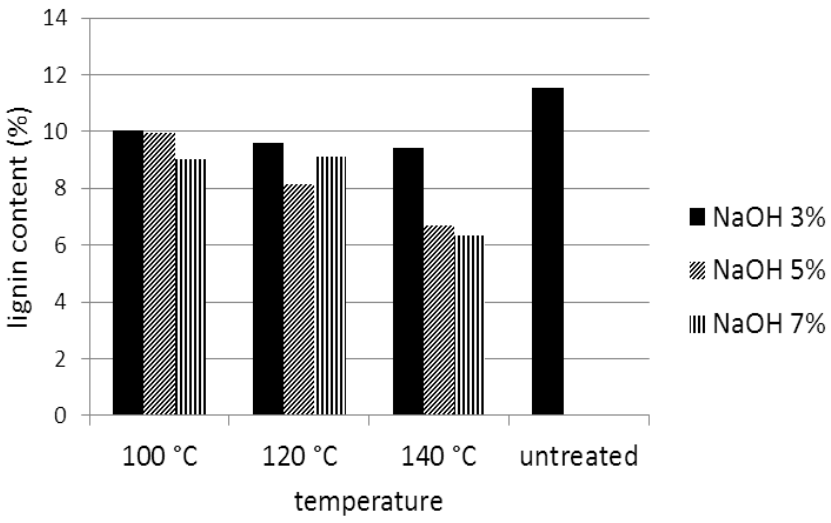

Fig. 3 Lignin content before and after hydrothermal treatment.

at $5 \% \mathrm{NaOH}$ concentration along with the increase in temperature, while the increase in delignification at $3 \% \mathrm{NaOH}$ concentration was not significant.

Lignin and hemicellulose which were soluble in hydrothermal product liquor causing the crystal portion of cellulose to increase. This explained the minimal changes in the degree of crystallinity as shown in Fig. 7. Similarly, the thermal decomposition rate at lower temperatures were obtained because the bonding in the cell wall of biomass weakened due to the loss of lignin and hemicellulose as shown in Fig. 10.

From a previous research conducted by Cheng et al. (2010), a treatment at $55{ }^{\circ} \mathrm{C}$ with $4 \% \mathrm{NaOH}$ for 3 hours resulting in delignification of $23.1 \%$. While research conducted by Imman et al. (2014) at $140{ }^{\circ} \mathrm{C}$ with $0.25 \% \mathrm{NaOH}(\mathrm{w} / \mathrm{v})$ and a 25 bar pressure resulting in the decrease of lignin from 24.4 to $11.3 \%$ with delignification of $53.68 \%$. Compared to this current study that employed the temperature of $140^{\circ} \mathrm{C}$ with a pressure of 2 bar, the lignin dissolution was smaller and cellulose content after treatment in this study did not increase significantly. Based on this comparison, it can be concluded that the increase in pressure can increase the solubility of lignin and hemicellulose (Du et al. 2011).

In a research conducted by Menardo et al. (2011), hydrothermal pretreatment of rice straw $3 \% \mathrm{NaOH}$ at $120{ }^{\circ} \mathrm{C}$ resulted in smaller lignin dilution with delignification of $9.63 \%$. This shows that the higher addition of $\mathrm{NaOH}$ to the hydrothermal process has an effect on larger lignin dissolution.

\section{Reducing sugar}

Analysis of sugar reduction concentration in filtrate of treatment result was performed using DNS method. Reducing sugars produced during the treatment process were resulting from hydrolysis of some hemicellulose and dissolved cellulose into sugar and furfural monomers (Imman et al., 2014). The result of sugar reduction analysis with DNS method after treatment as shown in Fig. 5. At a concentration of 3\% $\mathrm{NaOH}$, the increase in glucose yield in the filtrate of resulting treatment increases with the rise in temperature, whereas at concentrations of 5 and $7 \% \mathrm{NaOH}$ the reduction of sugar yields decreases with increasing temperature, it can be caused by degradation of reducing sugar to furfural.

From this research, the highest yield of reducing sugar was found at temperature of $120{ }^{\circ} \mathrm{C}$ and $\mathrm{NaOH}$ concentration of $5 \%$ with $1.3 \%$ reducing sugar yield. Comparison with previous research conducted by Imman et al. (2014) on rice straw with operating conditions of $140^{\circ} \mathrm{C}$, 25 bar and $0.25 \% \mathrm{NaOH}(\mathrm{w} / \mathrm{v})$ for 5,10 and 20 minutes to obtain a glucose-yield relationship graph with furfural, it was known that glucose yield decreases with the increasing time and furfural that was increase. The higher reducing sugar content will be more easily digested by biogas and bioethanol-forming microorganisms. While the formation of furfural during pre-treatment can cause the reduction of yield of reducing sugar so that it can affect biogas or bioethanol yield. 


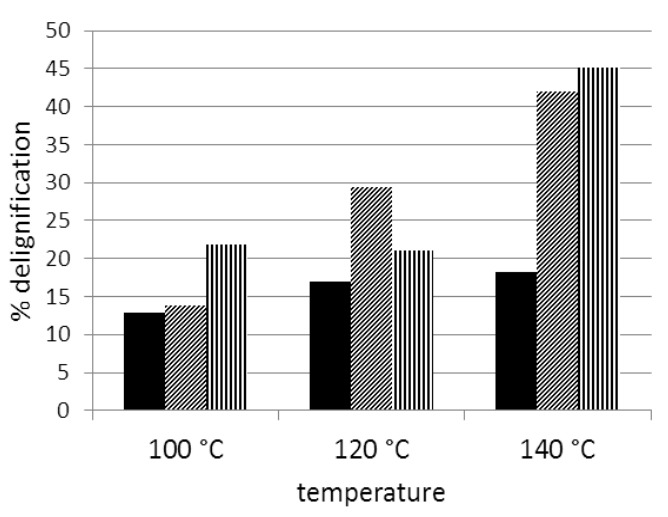

- $\mathrm{NaOH} 3 \%$

\% $\mathrm{NaOH} 5 \%$

IIII NaOH 7\%

Fig. 4 Influence of alkaline concentration and temperature during hydrothermal treatment on delignification.

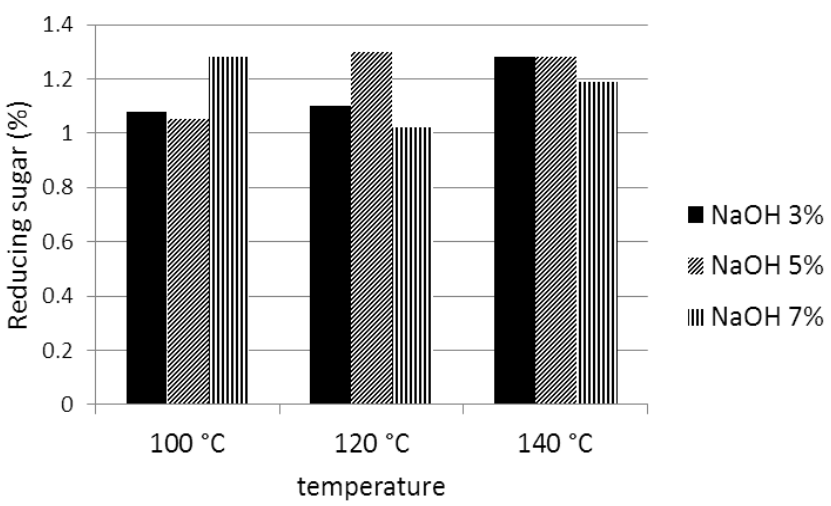

Fig. 5 Reducing Sugar concentration on the filtrate of hydrothermal treatment.

Reducing sugar is the most easily digestible component by microorganisms for biogas or bioethanol, hence this will play an important role in the productivity of biogas or bioethanol.

\section{Cellulose crystallinity}

Cellulose is a polymer with crystals and amorphous. The material contained in the crystal structure can be diffracted by X rays, so it can be used to find out the cellulose structure. The crystallinity index (CrI) is the ratio between the crystalline area and the total area of crystalline and amorphous. The amorphous compounds were removed during pretreatment are lignin and hemicellulose, leaving the crystal fraction and raising the crystallinity index (Haque et al., 2012). The graph of XRD data analysis without treatment and after treatment at $100{ }^{\circ} \mathrm{C}$ with $3 \%$ $\mathrm{NaOH}$ concentration is shown in Fig. 6 .

The XRD results from Fig. 6 shows the total crystallinity of all components contained in rice straw (cellulose, hemicellulose, lignin, and more). Some of the XRD graphs are seen to be similar to the XRD results of the pure cellulose (micro crystalline cellulose) reported by Yusnica et al. (2014) in Fig. 6, indicating that cellulose is a major component of the rice straw.

The equations used in the Crystalline Index determination by using the area area method (Poletto et al., 2012) are as follows:

$$
C r . I=\frac{A_{\text {crist }}}{A_{\text {total }}}
$$

Cr.I $=$ crystalisation index

$A_{\text {cryst }}=$ The total area of the crystal

$A_{\text {total }}=$ Total area of crystal and amorphous area

Summary of crystallinity index $(\mathrm{Cr} I)$ before and after pre-treatment are shown in Fig. 7. From Fig. 7, it can be seen that the index of crystallinity of rice straw decreased after hydrothermal treatment. The effect of $\mathrm{NaOH}$ concentration at $100{ }^{\circ} \mathrm{C}$ on the crystallinity index $(\mathrm{CrI})$ is seen to increase with the increase of $\mathrm{NaOH}$ concentration, while at 120 and $140{ }^{\circ} \mathrm{C}$ tends to decrease with the increase of $\mathrm{NaOH}$ concentration. Decrease in the index of crystallinity is indicated due to dissolved cellulose during the treatment process.

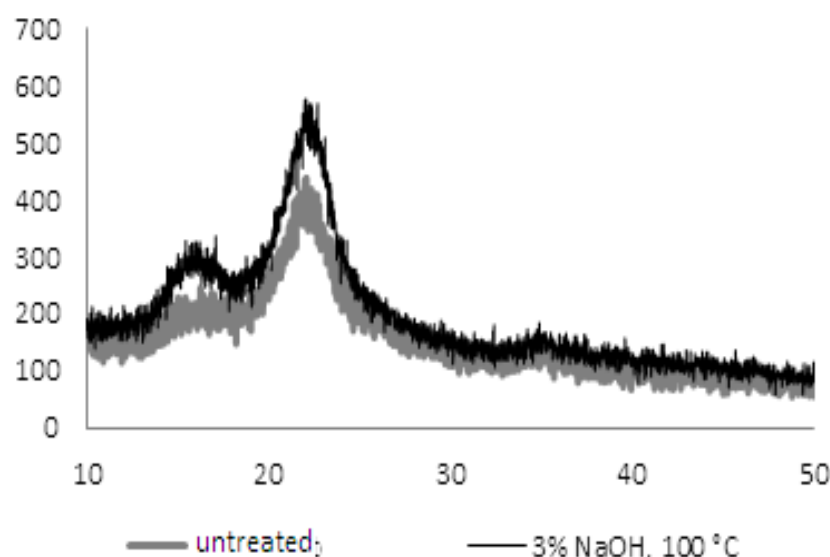

Fig. $6 \mathrm{XRD}$ chart of rice straw before and after hydrothermal treatment of $3 \% \mathrm{NaOH} 100^{\circ} \mathrm{C}$

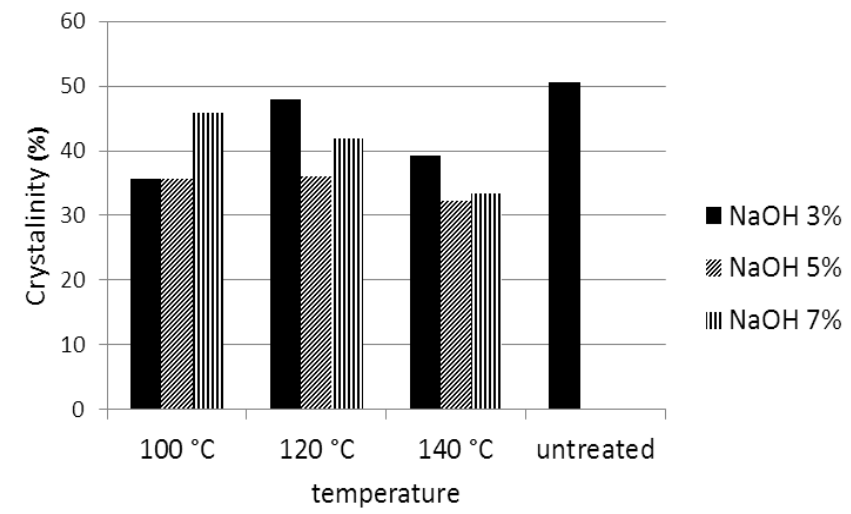

Fig. 7 Crystallinity Index before and after hydrothermal treatment.

The decrease in the crystallinity index (CrI) causes the degradability of rice straw to rise. This is due to the decrease of crystals in rice straw after hydrothermal treatment. The unchanged XRD pattern of cellulose crystals in rice straw before and after treatment was due to the fact that the treatment with $\mathrm{NaOH}$ only penetrated the crystal and amorphous surfaces, resulting in the swelling between the crystal areas (He et al., 2008). Meanwhile, in a research conducted by Bali et al. (2014), a treatment using $2 \% \mathrm{NaOH}$ concentration and temperature 120 ${ }^{\circ} \mathrm{C}$ for 60 minutes resulted in a fluctuation of $\mathrm{CrI}$.

\section{Formation of inhibitor material (furfural)}

Hydrothermal treatment of rice straw resulted the degradation of sugar in the product in the liquid fraction to form furfural $(0.008-0.063$ $\mathrm{mg} / \mathrm{mL}$ furfural). Fig. 8 shows the chart of the furfural concentration of the liquid from treated rice straw. Maximum furfural formation was observed at a treatment temperature of $140{ }^{\circ} \mathrm{C}, 5 \% \mathrm{NaOH}$, which corresponds to the condition with the highest observed yield on depolymerization producing sugars. The addition of bases lead to higher sugar yields in the hydrolysis of solids. Imman et al. (2015) found that glucose and pentose were removed as the main sugar from cellulose hydrolysis and hemicellulose in the treated rice straw. Higher $\mathrm{NaOH}$ concentration were observed to reduce glucose yield. Elevating $\mathrm{NaOH}$ content may cause the loss of sugar from glucan hydrolysis into monomer sugars and other degradation products.

Effect of temperature on efficiency and treatment selectivity was studied at high temperatures $\left(100-160{ }^{\circ} \mathrm{C}\right)$. Increased treatment temperature results in increased cellulose hydrolysis with higher concurrent glucose in the liquid phase. The resulting increase in sugar content with temperature coincided with the increased accumulation of inhibiting products. 


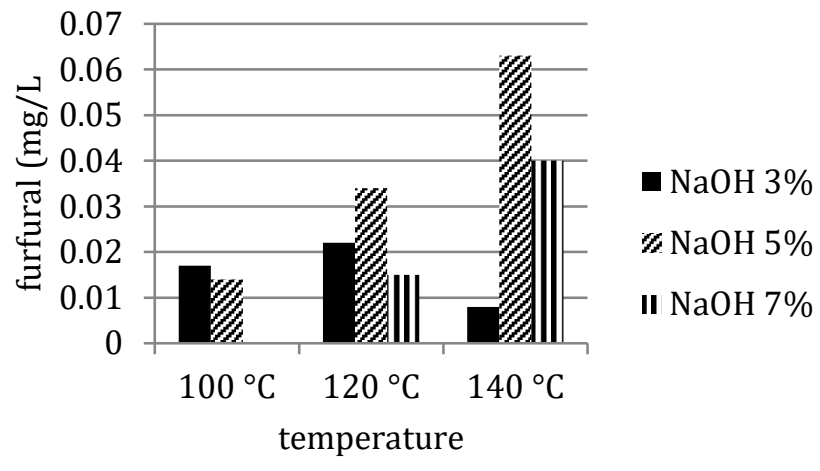

Fig. 8 Furfural concentration on treated of rice straw.

The highest furfural content $(0.063 \mathrm{mg} / \mathrm{mL})$ was observed at 140 ${ }^{\circ} \mathrm{C}$ using $5 \% \mathrm{NaOH}$. Lower concentrations of sugar degradation were found in the presence of lower base and temperature.

Furfural plays an important role in the productivity of biogas or bioethanol due to poisonous properties of this substance. The trend of furan formation of sugar degradation was observed from further degradation of monomer sugars under the acidic environment (Ertas et al., 2014). The accumulated concentration of furan present in a higher alkaline treatment process than in the absence of $\mathrm{NaOH}$. It also showed that the furan compound decreased with increasing concentration of $\mathrm{NaOH}$ (from $5 \%$ to $7 \%$ ) in the temperature range of $140{ }^{\circ} \mathrm{C}$. This could be due to the promotion of furan condensation reaction by $\mathrm{NaOH}$ (Amarasekara et al., 2013). But the furfural concentration was still below $2 \mathrm{mg} / \mathrm{mL}$, which is the threshold of inhibition for ethanologens (Sanchez et al., 1998). Therefore, direct fermentation of prehydrolyzates is feasible for further conversion to biofuels or chemicals via fermentation routes.

\section{Thermogravimetric analysis (TGA)}

The result of TGA analysis for treatment of rice straw at temperature of $140{ }^{\circ} \mathrm{C}$ is shown in Figs. 9 and 10. The analysis under non atmospheric conditions was performed to evaluate the pyrolytic behavior of the biomass curve. The TGA results showed that the devolatilization process begins at $150{ }^{\circ} \mathrm{C}$ and the maximum weight loss occurs in the range of $200-350{ }^{\circ} \mathrm{C}$. Above $370{ }^{\circ} \mathrm{C}$, a sudden change in the TGA curve occured that leads to slower weight loss within the temperature range of $350-400{ }^{\circ} \mathrm{C}$. The evaluation of the weight reduction of the sample was carried out between the temperature of 120 ${ }^{\circ} \mathrm{C}$, i.e. at the end of the evaporation of water, and ended at $550{ }^{\circ} \mathrm{C}$, indicating that more than $70 \%$ by weight of the fly material was removed at this interval.

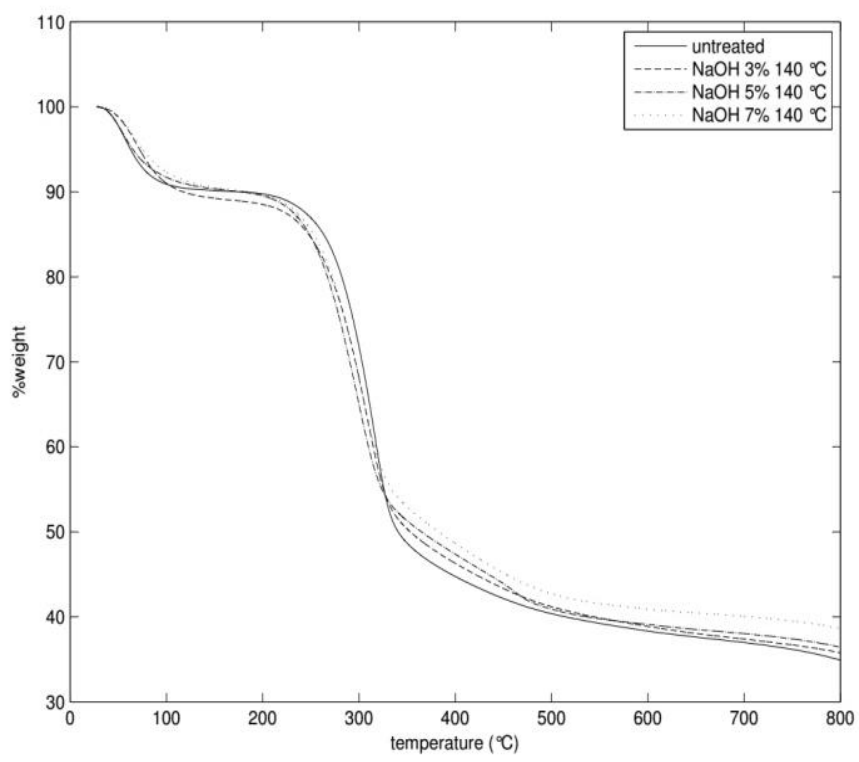

Fig 9. TGA curve for treated rice straw at temperature of $140{ }^{\circ} \mathrm{C}$.

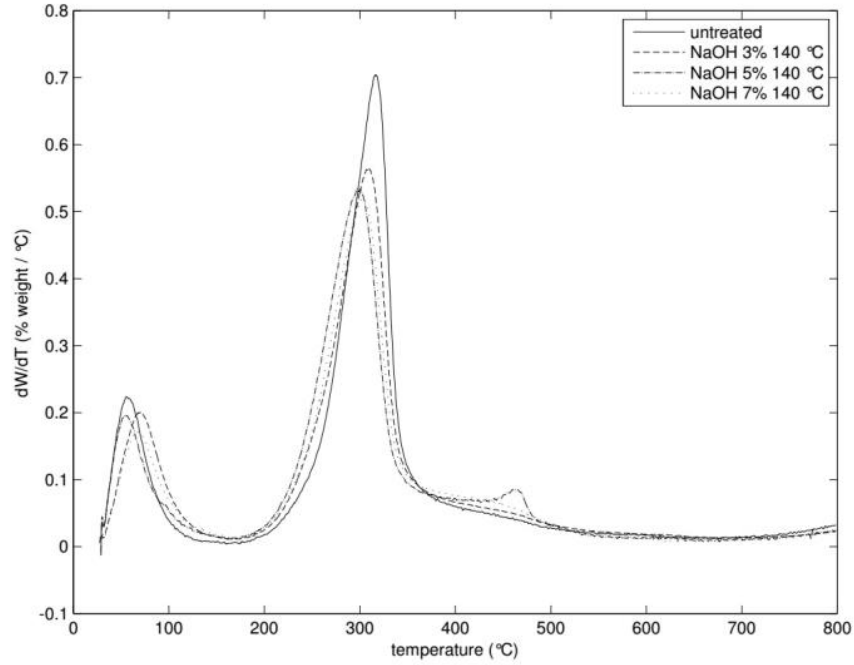

Fig. 10 DTG curve for treated rice straw at temperature of $140{ }^{\circ} \mathrm{C}$.

Fig. 10 shows the thermogravimetric differential curve (DTG) obtained from treated and untreated rice straw. The biomass curve produces three major peaks of biomass pyrolysis:, hemicellulose in the $200-300{ }^{\circ} \mathrm{C}$ temperature range; $\alpha$-cellulose in the $250-350{ }^{\circ} \mathrm{C}$ range; and lignin in the $200-500{ }^{\circ} \mathrm{C}$ range. The relative intensity of the peaks might be related to the global content of hemicellulose, cellulose, and lignin present in biomass.

The DTG curve shows the presence of hemicellulose and cellulose in high proportions. In addition, the presence of peaks at higher temperatures indicated traces of lignin in the sample. The DTG curve of hemicellulose and a-cellulose given by Carrier et al. (2011) shows a larger peak that corresponds to high concentrations. However, its peak presence in the $200-300{ }^{\circ} \mathrm{C}$ temperature range confirms that the hemicellulose was still considerable in the sample. The lignin DTG curve obtained from washable biomass after acid hydrolysis (Carrier, 2011) was known to break down slowly over a wide temperature range, thus forming a flat tail portion of the DTG curve.

\section{CONCLUSION}

The effect of $\mathrm{NaOH}$ as an external base on rice straw treatment was demonstrated in this study. It was found that the presence of $\mathrm{NaOH}$ enhanced the enzymatic hydrolysis of rice straw. Cellulose and lignin were removed from the solid residue and high sugar yields were obtained in the liquid phase. Hydrothermal treatment in alkaline condition resulted in the dissolvemnt of lignin and hemicellulose. The higher the temperature and the concentration of $\mathrm{NaOH}$, the more lignin and soluble hemicellulose. Crystallinity of solid product of hydrothermal treatment also showed a lower crystalinity index at higher the temperature and concentration of $\mathrm{NaOH}$. Thermal decomposition rate has also shown to be faster at lower temperature

\section{ACKNOWLEDGEMENT}

This work was financially supported by the Ministry of Research and Higher Education Indonesia under the scholarship program (BPPDN).

\section{REFERENCES}

Amarasekara, Singh, T. B., Larkin, E., Hasan, M. A., Fan, H. J. NaOH catalyzed condensation reactions between levulinic acid and biomass derived furanaldehydes in water, Industrial Crops and Products, in press.

Bali, G., Meng, X., Deneff, J. I., Sun, Q., Ragauskas, A. J. 2014. The effect of alkaline pretreatment methods on cellulose structure and accessibility ChemSusChem Communications, 00, $1-5$.

Carrier, Marion, Loppinet-Serani, A., Denux, D., Lasnier, J-M., Ham-Pichavant, F., Cansell, F., Aymonier, C. 2011 Thermo-gravimetric analysis as a new method to determine the lignocellulosic composition of biomass. Biomass and Bioenergy, 35, $298-307$. 
Cheng, Y. S., Zheng, Y., Yu, C. W., Dooley, T. M., Jenkins, B. M., Vandergheynst, J. S. 2010. Evaluation of high solids alkaline pre-treatment of rice straw. Biotechnology and Applied Biochemistry, 162, 1768-1784.

Demirbas M. F., Balat M., Balat H. 2009, Potential contribution of biomass to the sustainable energy development. Energy Conversion and Management, $50,1746-1760$.

Du, S. K., Zhu, X., Wang, H., Zhou, D., Yang, W., Xu, H. 2013. High pressure assist-alkali pretreatment of cotton stalk and physiochemical characterization of biomass. Bioresource Technology, 09, 020

Ertas, Han, Q., Jameel, H. 2014. Acid-catalyzed autohydrolysis of wheat straw to improve sugar recovery. Bioresource Technology, 169, 1-8.

Gerardi M. H. 2003. The Microbiology of Anaerobic Digesters. New Jersey: John Wiley \& Sons, Inc.

Haque, Azizul, M., Barman, D. N., Kang, T. H., Kim, M. K., Kim, J., Kim, H., Yun, H. D. 2012. Effect of dilute alkali on structural features and enzymatic hydrolysis of barley straw (hordeum vulgare) at boiling temperature with lowresidence time. Journal of Microbiology and Biotechnology, 22(12), 1681-1691.

He, Y. F., Pang, Y., Liu, Y., Li, X., Wang, K. 2008 Physicochemical characterization of rice straw pre-treated with sodium hydroxide in the solid state for enhancing biogas production. Energy \& Fuels, 22, 2775-2781.

M. Ertas, Q. Han, H. Jameel. 2014. Acid-catalyzed autohydrolysis of wheat straw to improve sugar recovery. Bioresource Technology, 169, 1-8.

Imman, S., Arnthong, J., Burapatana, V., Champreda, V., and Laosiripojana, N. 2014. Effects of acid and alkali promoters on compressed liquid hot water pretreatment of rice straw. Bioresource Technology, 171, 29-36.

Kim, S., M. T. Holtzapple. 2005. Lime pretreatment and enzymatic hydrolysis of corn stover. Bioresource Technology, 96, 1994-2006.

Kim, T. H., Y. Y. Lee. 2005. Pretreatment and fractionation of corn stover by ammonia recycle percolation process. Bioresource Technology, 96, 20072013.

Liu, L., J. Sun, M. Li, S. Wang, H. Pei, and J. Zhang. 2009. Enhanced enzymatic hydrolysis and structural features of corn stover by $\mathrm{FeCl} 3$ pretreatment. Bioresource Technology, 100, 5853-5858.

Menardo, S., Airoldi, G., dan Balsari, P. 2011, The effect of particle size and thermal pre-treatment on the methane yield of four agricultural by-products. Bioresource Technology, 104, 708-714.

Poletto, M., Zattera, A. J., Forte, M. M. C., Santana, R. M. C. 2012. Thermal decomposition of wood: Influence of woodcomponents and cellulose crystallite size. Bioresource Technology, 109, 148-153.

B. Sanchez, J. Bautista. Effects of furfural and 5-hydroxymethylfurfural on the fermentation of Saccharomyces cerevisiae and biomass production from Candida guilliermondii. Enzyme and Microbial Technology, 10 (1998) 315318.

Sakaki, T., Shibata, M., Sumi, T., Yasuda, S. 2002 Saccharification of cellulose using a hot-compressed water-flow reactor. Industrial \& Engineering Chemistry Research, 41, 661-665.

Silalertruksa, T., Gheewala, S. H., Sagisaka, M., Yamaguchi, K. 2003. Life cycle GHG analysis of rice straw bio-DME production and application in Thailand. Applied Energy, 112, 560-567.

Wisniewska, S. K., J. Nalaskowski, E. Witka-Jezewska, J. Hupka, and J. D Miller. 2003. Surface properties of barley straw. Colloids and Surfaces A, 29, 131-142.

Yusnica, S., Sangian, H. F., Gunawan, S., dan Widjaja, 2014, A. Pretreatment of sugarcane bagasse with $\mathrm{NaOH}$ and [DMIM][DMP] for efficient hydrolysis department of chemical engineering. Bulletin of Chemical Reaction Engineering and Catalysis, 10(1), 2015, 70-77.

Zheng, Y., Zhao, J., Xu, F., Li, Y. 2014. Review Pre-treatment of lignocellulosic biomass for enhanced biogas production. Progress in Energy and Combustion Science, 42, 35-53. 